\title{
Obituário
}

\section{Katia de Queiroz Mattoso: obituário de um membro do Conselho da RBPI}

PAULO ROBERTO DE ALMEIDA*

Sou suspeito para escrever sobre a professora e, sobretudo, amiga Katia de Queiroz Mattoso, por uma ou duas razões muito simples: eu era um admirador de sua obra, e com ela assinei um pequeno livro de história do Brasil, publicado em Paris, em 2002. Tive a ideia assim que cheguei em Paris, em 1993, e fui visitá-la, pedindo autorização para que um texto seu, sobre a história do Brasil dos tempos coloniais até o final do regime militar, fosse editado pela Embaixada do Brasil, para uso dos estudantes secundaristas franceses, com um complemento meu sobre a fase contemporânea, até o final do governo Itamar Franco. O panfleto teve bom acolhimento entre as escolas, daí nossa decisão de passar a uma edição comercial, ampliada, graças a nosso bom amigo Denis Rolland, editor da coleção latinoamericana da Harmattan, uma editora essencialmente universitária.

Estive em seu apartamento diversas vezes, numa pracinha fechada, perto da Avenue Victor Hugo, invariavelmente para encontros com historiadores brasileiros, franceses, americanos, enfim, com a pequena République des Lettres que circulava em torno da nossa grande dame da cadeira de Histoire du Brésil na Sorbonne (ParisIV), aonde fui diversas vezes, palestrar ou assistir aulas e dissertações sobre os mais diversos temas da história do Brasil e assuntos correlatos. Ela tinha um gabinete minúsculo na Sorbonne, mas sua casa estava sempre aberta aos muitos estudantes brasileiros, franceses ou de quaisquer outras nacionalidades que desejassem estudar o Brasil, em todos os seus aspectos. Todo historiador brasileiro passando pela França - e eles sempre foram muitas dezenas - tinha de falar com a "Katia", o que geralmente terminava por uma sessão de conversa e de chá em seu apartamento acolhedor.

Também sou suspeito para falar (bem) dela, pois fui eu quem tomou a decisão de agraciá-la com a Ordem do Rio Branco, assim que a oportunidade se apresentou. Com razão, com mérito e com honra, pois pouca gente fez tanto pelo estudo da história do Brasil na França (e no mundo, pois alguns de seus livros e trabalhos foram também traduzidos para o inglês) quanto essa grega de origem, brasileira por casamento e baiana de coração. Minhas afinidades com ela também passavam pela carreira diplomática, já que ela também teve sua primeira experiência, no serviço

*PhD em Ciências Sociais e diplomata de carreira (pralmeida@me.com). 
exterior da Grécia, muito jovem, servindo como adida cultural na Embaixada da Grécia em Berna, que foi também meu primeiro posto diplomático, onde retomei um doutoramento interrompido algum tempo antes do final do regime militar. Intercambiávamos nossas impressões diplomáticas e assim ficamos amigos até o final, amizade partilhada com Carmen Lícia, minha esposa historiadora, a quem Katia ajudou muito nos contatos com bibliotecas, arquivos e historiadores franceses, na fase de pesquisa para sua tese de doutoramento sobre os viajantes franceses no Brasil, nos primeiros séculos da colonização.

Nos muitos encontros que tivemos em Paris - e depois, em visitas ocasionais - falávamos sobre tudo, especialmente sobre a Bahia, onde ela tinha vivido por longos anos e onde tinha dado aulas de história nas universidades federal e Católica de Salvador, e que tinha sido o objeto de sua monumental tese de Doctorat d'État (apresentada a uma banca respeitável em 1986), feita num modelo braudeliano e abordando a história social e econômica da mais importante província do Império. A tese foi mais tarde traduzida do francês e publicada pela Nova Fronteira (1992), como Bahia, século XIX: uma província no Império, tendo sido muito bem acolhida pela crítica especializada como a mais perfeita tradução da metodologia da escola dos Annales aplicada ao Brasil. De fato, esse trabalho condensa o que de mais importante se pesquisou e se escreveu sobre a Bahia nos planos antropológico, social, econômico e político, a partir de pesquisas de arquivo e de farto material secundário. Mas ela ficou mais famosa bem antes, talvez, pelo seu Etre esclave au Brésil (diversas edições em várias línguas), que renovou metodologicamente os estudos nessa área.

Ainda mais importante, provavelmente, foi seu trabalho como professora e orientadora de dezenas de estudantes brasileiros e estrangeiros, em todos os cursos de que foi responsável ou de que participou, na Bahia e na França. A cadeira de História do Brasil na Sorbonne foi criada especialmente para ela, tanto em homenagem ao seu trabalho quanto em reconhecimento a seus esforços para elevar a qualidade e o padrão dos estudos sobre o Brasil na França. Essa área estava anteriormente entregue a mestres franceses que, certamente, conheciam o Brasil e que aqui tinham vivido, mas que não tinham a sua sensibilidade de baiana e de brasileira para interpretar as peculiaridades de nossa trajetória histórica com o instrumental analítico francês e com o conhecimento profundo dos documentos e da sociedade brasileira. Essa cadeira, depois de sua aposentadoria da Sorbonne, passou aos cuidados do historiador Luís Felipe de Alencastro, que também conhece profundamente os arquivos brasileiros e africanos e a escola histórica francesa. Lembro-me de seminários na Sorbonne em que os dois pontificavam sobre episódios relevantes de nossa história passada e presente.

Ela deixou muitos netos e bisnetos, no Brasil e na Grécia, e muitas saudades nos seus muitos amigos em três ou quatro continentes. Ela faleceu em 11 de janeiro de 2011, em Paris, França, aos 78 anos, e foi enterrada na tumba da família, em sua Grécia natal. A Revista Brasileira de Política Internacional orgulha-se de ela ter 
aceitado integrar seu Conselho Editorial, e rende aqui uma homenagem modesta, mas sincera, a uma de nossas maiores historiadoras. Um livro em sua homenagem tinha sido organizado por um dos membros de sua banca de doutorado - de fato seu orientador, François Crouzet - e publicado na França quase dez anos atrás. Seus colegas professores da Universidade Federal da Bahia, da qual ela ostenta o título de Doutora Honoris Causa, poderiam organizar um novo volume em sua homenagem.

Recebido em 17 de maio de 2011 Aprovado em $1^{\circ}$ de junho de 2011 